Bangladesh J. Plant Taxon. 21(1): 71-76, 2014 (June)

(C) 2014 Bangladesh Association of Plant Taxonomists

\title{
SEED GERMINATION BEHAVIOUR OF SIX MEDICINAL PLANTS FROM BANGLADESH
}

\author{
Aleya Ferdousi, Md. Oliur Rahman ${ }^{1}$ and Md. Abul Hassan \\ Department of Botany, University of Dhaka, Dhaka-1000, Bangladesh
}

Keywords: Medicinal plants; Seed germination; Bangladesh.

\begin{abstract}
This paper focuses on seed germination of six indigenous medicinal plants of Bangladesh, namely Adenanthera pavonina L., Helicteres isora L., Murraya paniculata (L.) Jack, Psoralea corylifolia L., Uraria lagopodioides (L.) Desv. and U. picta (Jacq.) Desv. ex DC. The minimum days taken to germinate seeds in Adenanthera pavonina L., Murraya paniculata (L.) Jack, Psoralea corylifolia L., Uraria lagopodioides (L.) Desv. and $U$. picta (Jacq.) Desv. ex DC. are 12, 36, 10, 39 and 14, respectively. Seeds were not germinated in Helicteres isora L. indicating that seeds are not suitable for propagation, however, propagation through stem cutting in this species revealed that plants flowers and set fruits in the same year and take only six to seven months. Epigeal type of seed germination was observed in all cases.
\end{abstract}

\section{Introduction}

Medicinal plants play an important role in human life since they are employed as raw materials for the extraction of active constitution in pure form, as precursor for synthetic vitamins and steroids, and as preparations for herbal and indigenous medicines (de Padua et al., 1999). Yusuf et al. (2009) documented 747 species of medicinal plants occurring in Bangladesh. Adenanthera pavonina L., Helicteres isora L., Murraya paniculata (L.) Jack, Psoralea corylifolia L., Uraria lagopodioides (L.) Desv. and U. picta (Jacq.) Desv. ex DC. are six important medicinal plants commonly found in the country and used in traditional medicine. Seeds of Adenanthera pavonina L. (Fabaceae) are used in the treatment of boils, inflammation, cholera and paralysis (Ghani, 2003). Leaf paste of Helicteres isora L. (Sterculiaceae) is used in the treatment of eczema, while stem bark and roots are considered to be demulcent, expectorant, astringent and antigalactagogue, and are employed for treating dysentery, diarrhoea and biliousness (Ghani, 2003). Leaves of Murraya paniculata (L.) Jack (Rutaceae) are astringent, and used in diarrhoea and dysentery; a decoction of leaves is taken in dropsy and powdered leaf is applied to fresh cuts (Yusuf et al., 2009). Psoralea corylifolia L. (Fabaceae) is claimed to be useful in skin disorders, eczema and hair loss; fruits are laxative, aphrodisiac and are used for the treatment of leucoderma and leprosy; while seeds are used as laxative, diaphoretic, stomachic and anthelmintic (Ghani, 2003). Uraria lagopodioides (L.) Desv. is used in remittent fever, asthma, dysentery and for treatment of inflammation in chest. Decoction of leaves is used in diarrhoea (Yusuf et al., 2009). U. picta (Jacq.) Desv. ex DC. a source of antiseptic and leaves are used in gonorrhoea; roots are aphrodisiac and decoction of roots is used in fever and cough (Yusuf et al., 2009).

The germination response pattern of seeds is an important phenomenon in plant life history strategy (Mayer and Poljakoff-Mayber, 1989). In the recent past studies on seed germination and reproductive biology on different groups of plants have received considerable attention (Chauhan and Johnson, 2008; Liebst and Schneller, 2008; Vandelook and van Assche, 2009; Clements et al., 2010; Han and Long, 2010; Kameneva and Koksheeva, 2013), however, very little is known on

${ }^{1}$ Corresponding author. E-mail: prof.oliurrahman@gmail.com 
the seed germination pattern of medicinal plants (Hassan and Fardous, 2003; Liza et al., 2010; Rahman et al., 2012). Since medicinal plants are employed for primary healthcare system, emphasis to be given on seed germination patterns of medicinal plants, as in many cases they need to bring under cultivation. However, no earlier study has surveyed germination patterns in the medicinal plants employed in the present study. Therefore, the objective of the present work is to explore seed germination pattern and dormancy of seeds in Adenanthera pavonina L., Helicteres isora L., Murraya paniculata (L.) Jack, Psoralea corylifolia L., Uraria lagopodioides (L.) Desv. ex DC. which might help in bringing the plants under cultivation.

\section{Materials and Methods}

Six medicinally important plants selected for this study are Adenanthera pavonina L., Helicteres isora L., Murraya paniculata (L.) Jack, Psoralea corylifolia L., Uraria lagopodioides (L.) Desv. and U. picta (Jacq.) Desv. ex DC. Plants materials were collected from different areas of the country and planted in the Botanical Garden of Dhaka University for closer observation and critical study. The voucher specimens are deposited in Dhaka University Salar Khan Herbarium (DUSH).

Seeds of six species were collected from mature fruits and preserved under laboratory condition. Rahman et al. (2012) was followed for seed germination experiment. For sowing of the seeds earthen pots of 10 inch in diameter filled up with a mixture of soil and compost (2:1). In order to prevent fungal infection and microbial contamination seeds were treated with fungicides prior to sowing. Ten mature seeds for each taxon were sown in earthen pots at different time intervals to record dormancy and viability, suitable time for germination, percentage and type of germination. Propagation through stem cutting was performed in Helicteres isora as seeds were not germinated in this species.

\section{Result and Discussion}

Seed germination study on six species revealed that seeds of Helicteres isora did not germinate, while seeds of the remaining five species, viz., Adenanthera pavonina, Murraya paniculata, Psoralea corylifolia, Uraria lagopodioides (L.) Desv. and U. picta germinated.

Results of seed germination in Adenanthera pavonina, Murraya paniculata and Psoralea corylifolia, Uraria lagopodioides and U. picta are presented in Table 1. The minimum days taken for germination of seeds in Adenanthera pavonina are 12 and the suitable time for seed sowing is April when the germination rate is the highest. Seeds of Murraya paniculata required minimum 36 days to germinate and the germination rate is found to be higher in April. In Psoralea corylifolia seeds were sown in different months but the highest percentage of seed germination was noted in July and the best time for seed sowing for this species is June. The minimum days taken to germinate the seeds were 10 .

The present study reveals that in Uraria picta seeds sown after collection in December (12.12.2011) did not germinate, whereas seeds sown in mid of April (15.4.12) took 14 days indicating the minimum time for its germination. It is evident that in Uraria lagopodioides seeds sown after collection in December (12.12.2011) were not germinated as well. The minimum days required for seed germination in this species is 39 when seeds sown near mid April (Table 1). 
Table 1. Results of seed germination of five species of medicinal plants.

\begin{tabular}{|c|c|c|c|c|c|c|}
\hline Species & $\begin{array}{l}\text { Date of } \\
\text { seed } \\
\text { collection }\end{array}$ & $\begin{array}{l}\text { Date of } \\
\text { seed } \\
\text { sowing }\end{array}$ & $\begin{array}{l}\text { No. of } \\
\text { seeds } \\
\text { sown }\end{array}$ & $\begin{array}{c}\text { No. of } \\
\text { seeds } \\
\text { germinated }\end{array}$ & $\begin{array}{c}\text { Days } \\
\text { taken to } \\
\text { germinate }\end{array}$ & $\begin{array}{c}\text { \% of } \\
\text { germination }\end{array}$ \\
\hline \multirow{3}{*}{ Adenanthera pavonina L. } & \multirow{3}{*}{ 19.12.2010 } & 4.3.2011 & 10 & 4 & $42-45$ & $40 \%$ \\
\hline & & 25.3.2012 & 10 & 6 & 15 & $60 \%$ \\
\hline & & 15.4.2012 & 10 & 10 & 12 & $100 \%$ \\
\hline \multirow{3}{*}{$\begin{array}{l}\text { Murraya paniculata (L.) } \\
\text { Jack }\end{array}$} & \multirow{3}{*}{ 29.1.2012 } & 1.2 .2012 & 10 & 2 & 42 & $20 \%$ \\
\hline & & 27.2.2012 & 10 & 2 & 36 & $20 \%$ \\
\hline & & 13.3.2012 & 10 & 3 & 38 & $30 \%$ \\
\hline \multirow{3}{*}{ Psoralea corylifolia L. } & \multirow{3}{*}{ 5.5. 2012} & 5.5 .2012 & 10 & 2 & 12 & $20 \%$ \\
\hline & & 19.6.2012 & 10 & 4 & $10-17$ & $40 \%$ \\
\hline & & 14.9.2012 & 10 & 2 & 13 & $20 \%$ \\
\hline \multirow{4}{*}{$\begin{array}{l}\text { Uraria lagopodioides } \\
\text { (L.) Desv. }\end{array}$} & \multirow{4}{*}{ 29.11. 2011} & 12.12 .2011 & 10 & 0 & - & - \\
\hline & & 1.1. 2012 & 10 & 0 & - & - \\
\hline & & 14.2.2012 & 10 & 1 & 80 & $10 \%$ \\
\hline & & 12.4 .2012 & 10 & 1 & 39 & $10 \%$ \\
\hline \multirow{4}{*}{$\begin{array}{l}\text { U. picta (Jacq.) Desv. ex } \\
\text { DC. }\end{array}$} & \multirow{4}{*}{ 7.12. 2011} & 12.12 .2011 & 10 & 0 & - & - \\
\hline & & 1.1. 2012 & 10 & 0 & - & - \\
\hline & & 27.2.2012 & 10 & 1 & 33 & $10 \%$ \\
\hline & & 15.4.2012 & 10 & 1 & 14 & $10 \%$ \\
\hline
\end{tabular}

In Helicteres isora, seeds were not germinated indicating that they are not suitable for propagation through seeds. Consequently other mode of propagation like stem cutting was done for this species. Table 2 shows result of stem cutting experiment for Helicteres isora. The result indicates that Helicteres isora can be propagated by stem cutting. Therefore, propagation should be done by stem cutting method. The study also indicates that plant from stem cutting takes only 5-6 months to flowers and set fruits. The development of seedlings from seeds/ stem cutting up to maturity in the taxa studied is displayed in Plate 1.

Table 2. Result of stem cutting experiment in Helicteres isora $\mathrm{L}$.

\begin{tabular}{ccccccc}
\hline $\begin{array}{c}\text { Date of } \\
\text { stem } \\
\text { cutting }\end{array}$ & $\begin{array}{c}\text { Length of } \\
\text { the stems } \\
(\mathrm{cm})\end{array}$ & $\begin{array}{c}\text { Date of leaf } \\
\text { bud } \\
\text { formation }\end{array}$ & $\begin{array}{c}\text { Time taken to } \\
\text { appear leaf bud } \\
\text { (days) }\end{array}$ & $\begin{array}{c}\text { Average } \\
\text { time (days) }\end{array}$ & $\begin{array}{c}\text { Date of } \\
\text { flowering }\end{array}$ & $\begin{array}{c}\text { Date of fruit } \\
\text { formation }\end{array}$ \\
\hline \multirow{3}{*}{17.4 .2012} & 25 & 18.5 .2012 & 32 & & 29.9 .2012 & 22.10 .2012 \\
& 25 & 18.5 .2012 & 32 & 34.5 & Died & Died \\
& 25 & 22.5 .2012 & 36 & & Died & Died \\
\hline
\end{tabular}



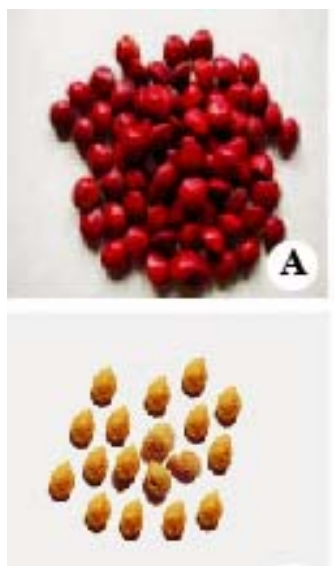

$\mathbf{E}$
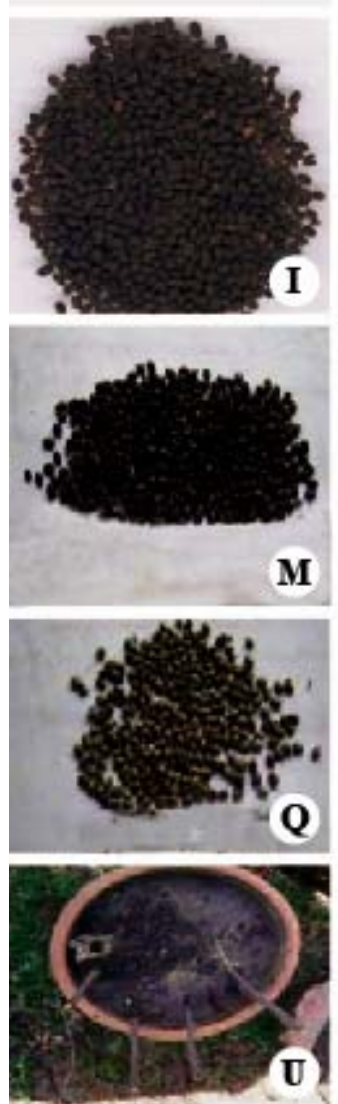
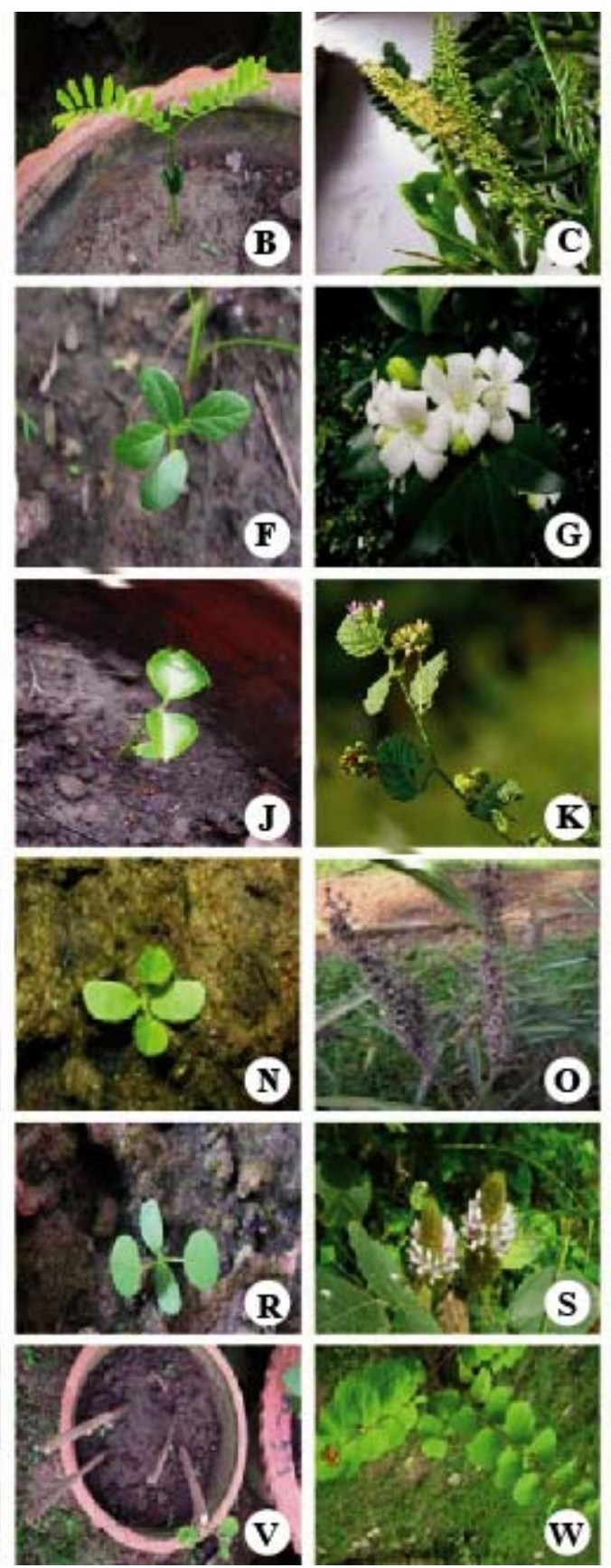
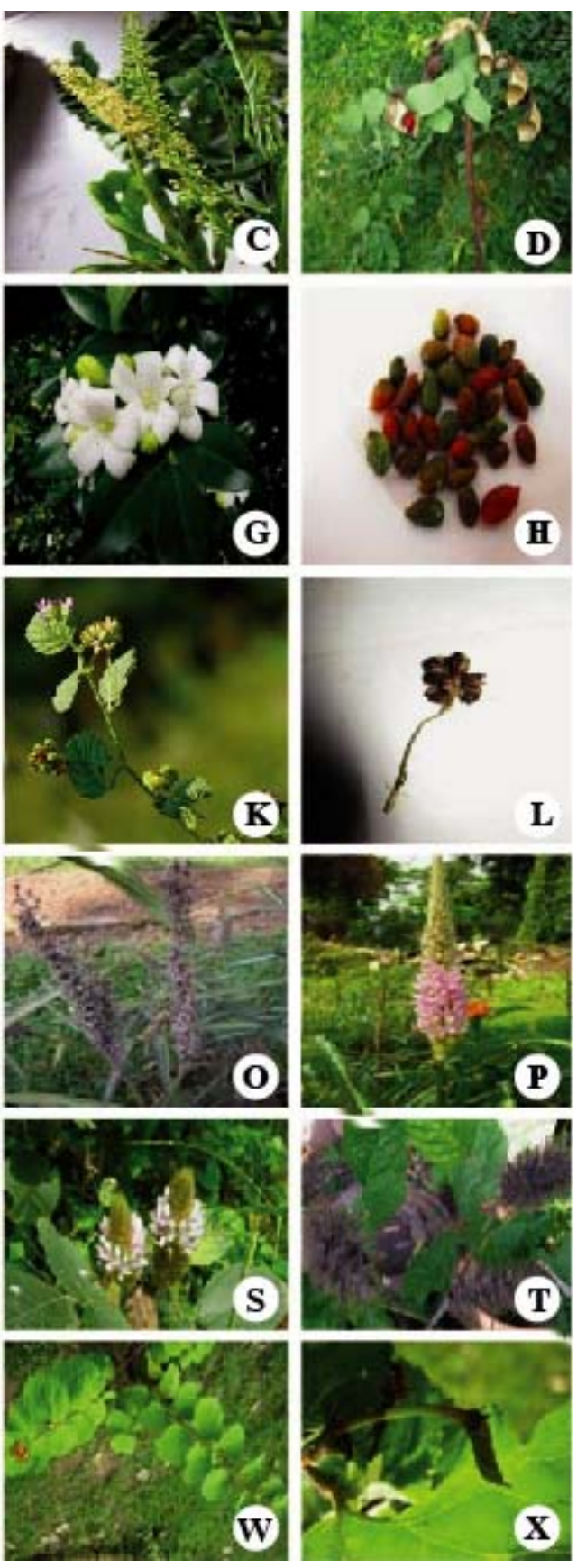

Plate 1. Development stages of six medicinal plants. A-D Adenanthera pavonina (A. seeds; B. seedling; C. mature plants with flowering stage; D. fruiting stage). E-H Murraya paniculata (E. seeds; F. seedling; G. mature plants with flowering stage; $\mathrm{H}$. fruits). I-L Psoralea corylifolia (I. seeds; J. seedling; K. mature plants with flowering stage; L. fruits). M-P Uraria lagopodioides (M. seeds; N. seedling; O. mature plants with flowering stage; P. fruiting stage). QT Uraria picta (Q. seeds; R. seedling; S. mature plants with flowering stage; T. fruiting stage). U-X Helicteres isora (U. stem cuttings; V. initiation of leaves; W. flowering; X. fruiting stage). 
In the present study we investigated seed germination of six medicinal plants. The present study reveals that epigeal germination is found in Adenanthera pavonina, Murraya paniculata, Psoralea corylifolia, Uraria lagopodioides and U. picta, whereas seeds of Helicteres isora failed to germinate. Time taken by the seeds to germinate varies from 10 days in Psoralea corylifolia to 80 days in Uraria lagopodioides (Table 1). Important factors controlling the variation in seed dormancy within species include the environment of the mother plant during the time of seed maturation and environmental conditions (Liebst and Schneller, 2008). Certain environmental conditions may be required to break dormancy, and other conditions are often required to permit germination after dormancy is broken (Foley, 2001). Seeds of many species require days, weeks, or months at low temperatures to break dormancy (Bewley and Black, 1994; Vleeshouwers et al., 1995), whereas others require warm temperatures for after-ripening to germinate when permissive conditions arrive (Baskin and Baskin, 1972). In the present study it required around two weeks to break the seed dormancy in Psoralea corylifolia, whereas, in Uraria lagopodioides it took one to three months to break the dormancy.

The environmental factors that could affect seed dormancy are time of seed harvest, length of seed storage, relative humidity and photoperiod (Baskin and Baskin, 1973). In this study seeds of different taxa were not collected at the same time because of the differences in the period of seed production among the taxa. Therefore, the level of dormancy observed may be affected by environmental factors. The level of dormancy observed may be affected by environmental factors. The number of days for germination is related to the size of seeds, the largest seeds germinated faster than the smaller seeds (Gerry and Wilson, 1995). However, our results were found incongruent with Gerry and Wilson (1995). Since different environmental factors affect on seed germination therefore it is necessary to carry out a detailed study considering the factors that might through more light on germination patterns which are considered to be of taxonomic importance (Vogel, 1980).

\section{References}

Baskin, J.M. and Baskin, C.C. 1972. Ecological life cycle and physiological ecology of seed germination of Arabidopsis thaliana. Can. J. Bot. 50: 353-360.

Baskin, J.M. and Baskin, C.C. 1973. Plant population differences in dormancy and germination characteristics of seeds: heredity or environment? Am. Midl. Nat. 90: 493-498.

Beweley, J.D. and Black, M. 1994. Dormancy and the control of germination. Seeds: physiology of development and germination. 2nd ed. Plenum, New York.

Chauhan, B.S. and Johnson, D.E. 2008. Influence of environmental factors on seed germination and seedling emergence of Eclipta (Eclipta prostrata) in a tropical environment. Weed Sci. 56: 383-388.

Clements, C.D., Harmon, D. and Young, J.A. 2010. Diffuse knapweed (Centaurea diffusa) seed germination. Weed Science 58: 369-373.

de Padua, L.S., Bunyapraphatsara, N. and Lemmens, R.H.M.J., 1999. Plant resources of south-east Asia, No. 12(1). Medicinal and poisonous plants 1 . Backhuys Publishers, Leiden, the Netherlands. 711 pp.

Foley, M.E. 2001. Seed dormancy: an update on terminology, physiological genetics, and quantitative trait loci regulating germinability. Weed Sci. 49: 305-317.

Gerry, A.K. and Wilson, S.D. 1995. The influence of initial size on the competitive responses of six plant species. Ecology 76: 272-279.

Ghani, A. 2003. Medicinal Plants of Bangladesh with Chemical Constituents and Uses (Second Edition). Asiatic Society of Bangladesh, Dhaka. 603 pp. 
Han, C.-Y. and Long, C.-L. 2010. Seed dormancy, germination and storage behavior of Magnolia wilsonii (Magnoliaceae), an endangered plant in China. Acta Bot. Yun. 32(1): 47-52.

Hassan, M.A. and Fardous, Z. 2003. Seed germination, pollination and phenology of Gloriosa superba L. (Liliaceae). Bangladesh J. Plant Taxon. 10(1): 95-97.

Kameneva, L.A. and Koksheeva, I.M. 2013. Reproductive biology of seven taxa of Magnolia L. in the south of Russian Far East. Bangladesh J. Plant Taxon. 20(2): 163-170.

Liebst, B. and Schneller, J.S. 2008. Seed dormancy and germination behavior in two Euphrasia species (Orobanchaceae) occurring in the Swiss Alps. Bot. J. Linn. Soc. 156: 649-656.

Liza, S.A., Rahman, M.O., Uddin, M.Z., Hassan, M.A. and Begum, M. 2010. Reproductive biology of three medicinal plants. Bangladesh J. Plant Taxon. 17(1): 69-78.

Mayer, A.M. and Poljakoff-Mayber, A. 1989. The germination of seeds. Pergamon Press, New York, NY.

Rahman, M.Z., Rahman, M.O. and Hassan, M.A. 2012. Seed germination of two medicinal plants: Desmodium pulchellum (L.) Benth. and D. triflorum (L.) DC. Bangladesh J. Plant Taxon. 19(2): 209-212.

Yusuf, M., Chowdhury, J.U., Haque, M.N. and Begum, J., 2009. Medicinal Plants of Bangladesh. Bangladesh Council of Scientific and Industrial Research, Chittagong, Bangladesh.

Vandelook, F. and van Assche, J.A. 2009. Temperature conditions control embryo growth and seed germination of Corydalis solida (L.) Clairv., a temperate forest spring geophyte. Plant Biology 11: 899-906.

Vleeshouwers, L.M., Bouwmeester, H.J. and Karssen, C.M. 1995. Redefining seed dormancy: an attempt to integrate physiology and ecology. J. Ecol. 83:1031-1037.

Vogel, E.F. 1980. Morphological types in dicot seedlings with reference to their origin. Bulletin de la Societe Botunique de France 126(3): 173-182. 